\title{
Analisa Perhitungan Dimensi Turap Kayu (Panjang Kayu Ditanam Dan Tebal) Sebagai Dinding Penahan Tanah Sementara
}

\author{
Ellyta Mona* \\ Teknik Sipil Fakultas Teknik Universita Batanghari Jambi \\ *Correspondence email: elytamona@gmail.co.id
}

\begin{abstract}
Abstrak. Pada saat ini perkembangan kontruksi penahan tanah terus dioptimalkan sesuai dengan penggunaan lahan yang tersedia, untuk menangani longsoran yang terjadi saat ini maupun dimasa yang akan datang. Struktur dinding penahan tanah (Turap) diharapkan dapat memberikan penyelesaian penanganan. Berdasarkan jenis material yang dipakai, dikenal beberapa tipe turap, yaitu; turap kayu, turap beton dan turap baja, dan berdasarkan jenis konstruksinya terdiri dari dua tipe yaitu; tipe kantilever dan tipe angkur. Sheet pile dari bahan kayu fungsi material ini adalah sebagai penahan tanah yang tidak begitu tinggi. Hal ini disebabkan material kayu tak akan sanggup dalam menahan beban tanah maupun kerikil yang berlebihan Dalam suatu penanganan untuk mengetahui fungsi ataupun perencanaan penanganan longsoran sangatlah penting, sebab dengan mengetahui tujuan dan fungsi dari perencanaan tersebut maka dapat lebih mudah dalam proses desain dan perencanaan, sehingga dalam perhitungan bagi segi mutu dan efisiensi penanganannya dapat tercapai sesuai dengan yang di inginkan. Tujuan dari penelitian ini adalah menganalisa perhitungan perencanaan dimensi turap kayu sementara (panjang kayu ditanam dan tebal) sebagai penahan tanah yang dibangun untuk mencegah terjadinya tanah longsor yang diakibatkan oleh intensitas hujan. Dari hasil penelitian yang telah dilakukan, perencanaan turap kayu lebar 1 meter dan 2 meter sebagai dinding penahan tanah dan untuk volume tanah berkisar dari $20 \mathrm{KN} / \mathrm{M}^{3}$ - $30 \mathrm{KN} / \mathrm{M}^{3}$ sedangkan tinggi turap 1 meter - 4 meter. Didapatkan bahwa panjang turap ditanam tidak mempengaruhi terhadap perubahan volume tanah sedangkan tebal kayu sangat mempengaruhi.
\end{abstract}

Kata Kunci: turap; kayu; dimensi; kantilever

Abstract. At this time, the development of retaining structures continues to be optimized according to the available land use, to deal with current and future landslides. The structure of the retaining wall (Turap) is expected to provide a solution for the handling. Based on the type of material used, several types of sheet pile are known, namely; wood sheet pile, concrete sheet pile and steel sheet pile, and based on the type of construction there are two types, namely; cantilever type and anchor type. Sheet pile made of wood, the function of this material is to retain the soil which is not so high. This is because the wood material will not be able to withstand excessive soil or gravel loads. In a handling, knowing the function or planning for handling avalanches is very important, because by knowing the purpose and function of the plan, it can be easier in the design and planning process. Calculations for the quality and efficiency of handling can be achieved as desired. The purpose of this study was to analyze the planning calculation of the dimensions of the temporary wood sheet pile (length of planted wood and thickness) as a soil barrier that was built to prevent landslides caused by the intensity of rain. From the results of the research that has been carried out, the planning of wooden sheet piles with a width of 1 meter and 2 meters as retaining walls and for soil volume ranges from 20 KN/M3-30 KN/M3 while the height of sheet piles is 1 meter - 4 meters. It was found that the length of the sheet pile planted did not affect changes in the volume of the soil while the thickness of the wood did.

Keywords: sheet pile; wood; dimensions; cantilever

\section{PENDAHULUAN}

Pada saat ini perkembangan kontruksi penahan tanah terus dioptimalkan sesuai dengan penggunaan lahan yang tersedia, untuk menangani longsoran yang terjadi saat ini maupun dimasa yang akan datang. Struktur dinding penahan tanah (Turap) diharapkan dapat memberikan penyelesaian penanganan. Sehubungan dengan hal diatas maka, mulailah dengan penanganan longsoran pada pengguna jalan didaerah perbukitan yang nantinya diharapkan dapat menunjang dan meningkatkan kenyamanan pengguna transportasi. Penanggulangan longsoran yang hanya berdasarkan pengalaman sebelumnya atau secara coba - coba pada umumnya kurang berhasil karena penanggulangannya belum tepat atau kurang memadai, sehingga dana yang digunakan kurang efektif (Eka Setyowati, 2012). Untuk itu di perlukan perencanaan turap secara baik, benar dan efisien. Sehingga longsoran dapat ditanggulangi dengan menggunakan turap yang telah diperhitungkan. Longsor yang terjadi dapat juga disebabkan karena sifat alam yang memiliki kemampuan untuk mengendalikan berbagai bentuk perubahan dengan membuat sesuatu yang baru dan seimbang. Asal mula dibuatnya konstruksi dinding penahan tanah adalah akibat bertambah luasnya kebutuhan konstruksi penahan yang digunakan untuk mencegah agar tidak terjadi kelongsoran menurut kemiringan alaminya. Sebagian besar bentuk dinding penahan tanah adalah tegak (vertikal) atau hampir tegak kecuali pada keadaan tertentu yang dinding penahan tanah dibuat condong ke arah urugan.

Pondasi turap adalah suatu konstruksi yang tersusun atas tiang-tiang turap yang digabungkan merapat antara satu sama lain, dimana kepala tiang turap 
dihubungkan secara kaku dengan caping (balok pengunci), sehingga diperoleh daya dukung vertikal dan tahanan lateral yang cukup (Martini, Shyama Maricar, Hendra Setiawan. 2012). Stabilitas konstruksi didapatkan akibat jepitan dalam tanah dan konstruksi angkur. Struktur pondasi turap lazim digunakan pada lokasi tebing jalan raya, tebing sungai, dinding dermaga, pondasi langsung atau pondasi menerus, basement, dll. Berdasarkan jenis material yang dipakai, dikenal beberapa tipe turap, yaitu; turap kayu, turap beton dan turap baja, dan berdasarkan jenis konstruksinya terdiri dari dua tipe yaitu; tipe kantilever dan tipe angkur. Sheet pile dari bahan kayu fungsi material ini adalah sebagai penahan tanah yang tidak begitu tinggi. Hal ini disebabkan material kayu tak akan sanggup dalam menahan beban tanah maupun kerikil yang berlebihan. Akan tetapi bukan berarti bahwa sheet pile ini tak bisa digunakan di atas permukaan air. Hanya saja ada syarat yag harus dipenuhi berupa pemberian lapisan pelindung pada permukaan sheet pile (Jambi Pos Online, 2016). Contoh penggunaan material ini adalah untuk menahan tebing galian, seperti diperlihatkan pada gambar 1 dibawah.

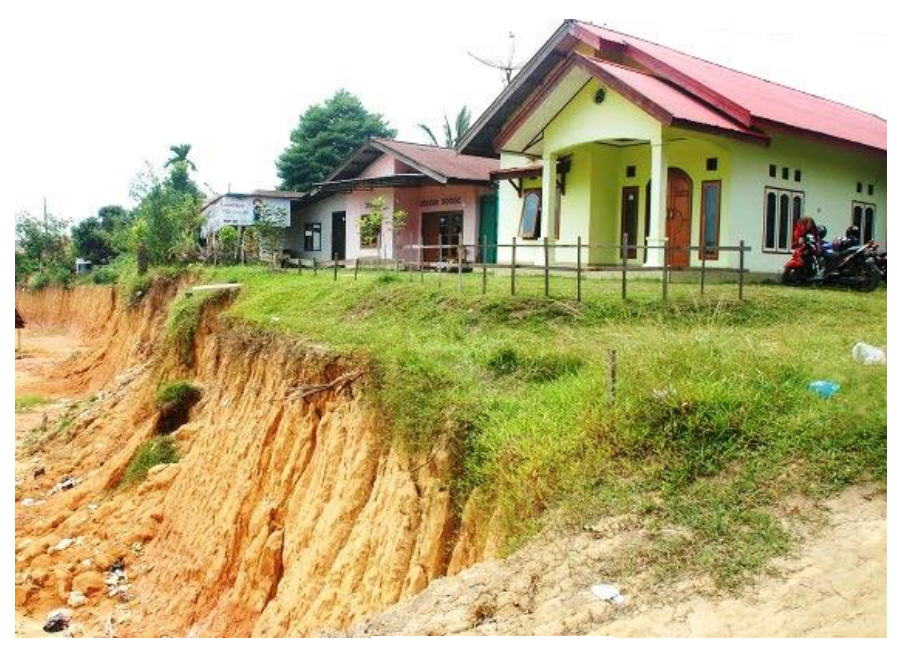

Gambar 1. Perencanaan turap sementara (turap kayu) sebagai penahan tanah

Sumber: Data Olahan (2016)

Tebing galian yang bersumber dari kelalaian masyarakat mengakibatkan tanah menjadi erosi akibat hujan seperti pada gambar 1 diatas, agar tidak bertambah parah maka akan di buat turap sementara menggunakan kayu, dalam suatu penanganan untuk mengetahui fungsi ataupun perencanaan penanganan longsoran sangatlah penting, sebab dengan mengetahui tujuan dan fungsi dari perencanaan tersebut maka dapat lebih mudah dalam proses desain dan perencanaan (Day, R.W.,1999), sehingga dalam perhitungan bagi segi mutu dan efisiensi penanganannya dapat tercapai sesuai dengan yang di inginkan.

Tujuan dari penelitian ini adalah menganalisa perhitungan perencanaan turap sementara (turap kayu) sebagai penahan tanah yang dibangun untuk mencegah terjadinya tanah longsor yang diakibatkan oleh intensitas hujan (Bowles, Joseph E., 1997).

\section{Rumus Perhitungan}

Teori Rankine menyatakan bahwa dalam analisis tekanan tanah literal menggunakan asumsi:

1. Tanah dalam kondisi kesetimbangan plastis (setiap elemen tanah dalam kondisi tepat akan runtuh)

2. Tanah urung di belakang turap tak berkohesi (c $=0$ )

3. Gesekan antara dinding turap dan tanah urung di abaikan $(\delta=0)$

Memperhitungkan kedalaman dan Dimensi Turap menggunakan persamaan sbb:

$$
\begin{aligned}
& k_{a}=\operatorname{tg}^{2}\left(45^{\circ}-\frac{\emptyset}{2}\right) \\
& k_{p}=\operatorname{tg}^{2}\left(45^{\circ}+\frac{\emptyset}{2}\right) \\
& E_{a}=1 / 2\left(H_{1}{ }^{2} x \gamma x k_{a}\right) \text {. } \\
& H_{1}=H+d_{0} \\
& e_{a}=1 / 3\left(2+d_{0}\right) \\
& E_{p}=1 / 2\left(d_{0}{ }^{2} x \gamma x k_{p}\right) \\
& e_{p}=1 / 3\left(d_{0}\right) \\
& W=1 / 6\left(b h^{2}\right) \text {. } \\
& \sigma_{i j i n} k a y u=\frac{M}{W} \text {. }
\end{aligned}
$$

\section{METODE}

Metode pada penelitian ini adalah melakukan perhitungan secara sistematis berdasarkan teori, sehingga dapat menyelidiki dimensi turap kayu yang akan direncanakan (Hardiyatmo, 2003). Adapun parameter penelitian adalah perubahan berat volume $(\gamma)$ tanah terhadap dimensi turap kayu yang digunakan terkait panjang dan tebal kayu.

\section{Metode Penyederhanaan}

1. Asumsi $\mathrm{D}_{0}$ berhimpit dengan $\mathrm{D}$

2. Gaya $\mathrm{K}$ diasumsikan bekerja pada $\mathrm{D}_{0}$

3. $\sum \mathbf{M}_{\mathrm{p}}$ dan $\sum \mathbf{M}_{\mathrm{A}}$, diperhitungkan terhadap $\mathrm{D}_{0}$

4. $\sum \mathbf{M} \mathrm{D}_{0}=0$, maka didapat $\mathrm{d}_{0}$ dan $\mathrm{d}=1,2 \mathrm{~d}_{0}$

5. Dimensi turap ditentukan dari $\mathbf{M}_{\max }$ yang terjadi 


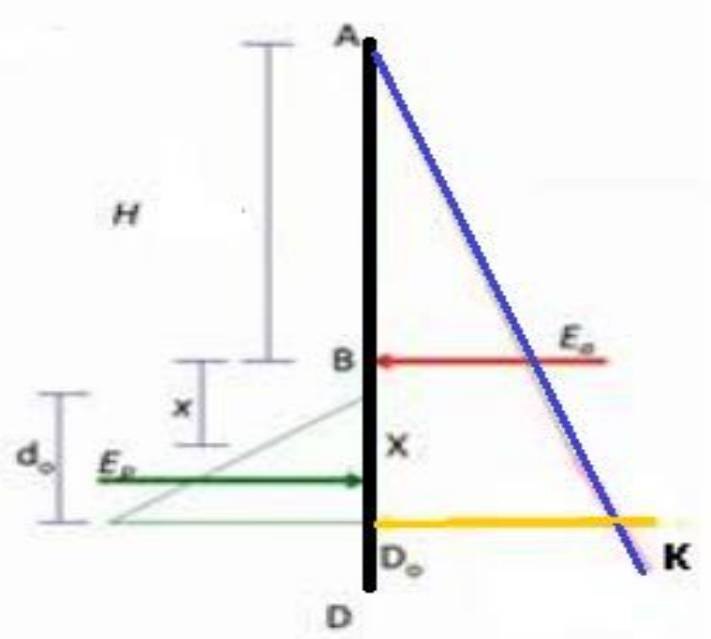

Gambar 2. Metode Penyederhanaan

\section{Tahap Pengumpulan Data}

Parameter pada penelitian di dapat dari kondisi lapangan kemudian perencanaan perkiraan tinggi turap $(\mathrm{H})$, lebar dan volume berat tanah akibat hujan, seperti pada tabel 1 dibawah.

Tabel 1. Parameter penelitian

\begin{tabular}{lc}
\hline & Parameter \\
\hline $\mathrm{H}$ & 1,5 Meter, 2 Meter, 2,5 Meter, 3 Meter, \\
& 3,5 Meter dan 4 Meter \\
$\sigma_{\text {ijin kayu }}$ & $20 \mathrm{Mpa}$ \\
$\Phi$ & $30^{\circ}$ \\
$\gamma$ & $20 \mathrm{KN} / \mathrm{M}^{3}$ dan $30 \mathrm{KN} / \mathrm{M}^{3}$ \\
Lebar & $1 \mathrm{Meter}$ dan $2 \mathrm{Meter}$ \\
Kohesi & - \\
\hline
\end{tabular}

\section{Tahap Analisa Data}

Menghitung dalam turap kayu yang ditanam dan menghitung tebal kayu turap yang digunakan

\section{Tahap Pembahasan}

Pembahasan yang dilakukan pada penelitian ini adalah mencari suatu persamaan Regresi Linier dimensi turap kayu (tebal dan panjang turap ditanam) yang didapatkan dari kecendrungan antara tinggi turap yang digunakan berdasarkan perubahan berat volume tanah.

\section{HASIL DAN PEMBAHASAN}

Hasil dari penelitian ini adalah menganalisa perhitungan perencanaan dimensi turap sementara (turap kayu) sebagai penahan tanah menggunakan software MATLAB, dengan perencanaan sebagai berikut:

1. Membuat suatu perancangan turap kayu dengan membuat suatu perencanaan tinggi turap $(\mathrm{H})$ yang akan dipasang dengan lebar 1 Meter dan berat volume tanah $(\gamma) 20 \mathrm{KN} / \mathrm{M}^{3}$. Adapun hasil perhitungan didapat pada tabel 2 dibawah.
Tabel 2. Hasil Perhitungan lebar 1 Meter dan volume

\begin{tabular}{lcccccc}
\multicolumn{7}{c}{$\operatorname{tanah}(\gamma) 20 \mathrm{KN} / \mathrm{M}^{3}$} \\
\hline \multicolumn{7}{c}{$(\gamma)$} \\
\multicolumn{1}{c}{$\left(20 \mathrm{KN} / \mathrm{M}^{3}\right)$} \\
DIMENSI & $\mathrm{H}(\mathrm{M})$ & $\mathrm{H}(\mathrm{M})$ & $\mathrm{H}(\mathrm{M})$ & $\mathrm{H}(\mathrm{M})$ & $\mathrm{H}(\mathrm{M})$ & $\mathrm{H}(\mathrm{M})$ \\
\hline Panjang turap ditanam(M) & 1,5 & 2 & 2,566 & 3 & 3,5 & 4 \\
Tebal (M) & 0,222 & 2,777 & 3,333 & 3,888 & 4,444 \\
\hline
\end{tabular}

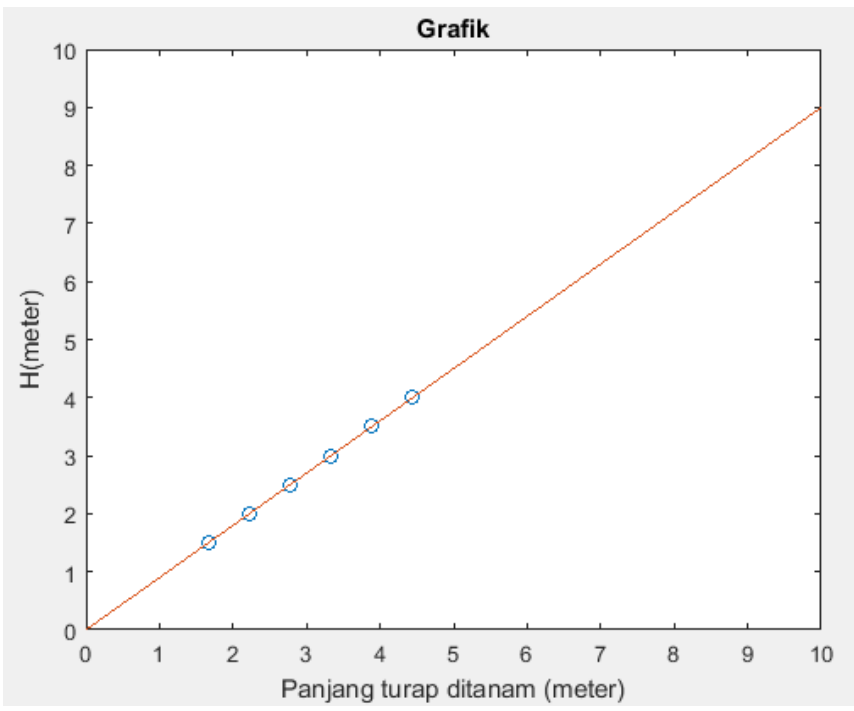

Gambar 3. Grafik Panjang Turap ditanam

Persamaan Regresi $\mathrm{Y}=-0.0005+1.1111 \mathrm{x}$

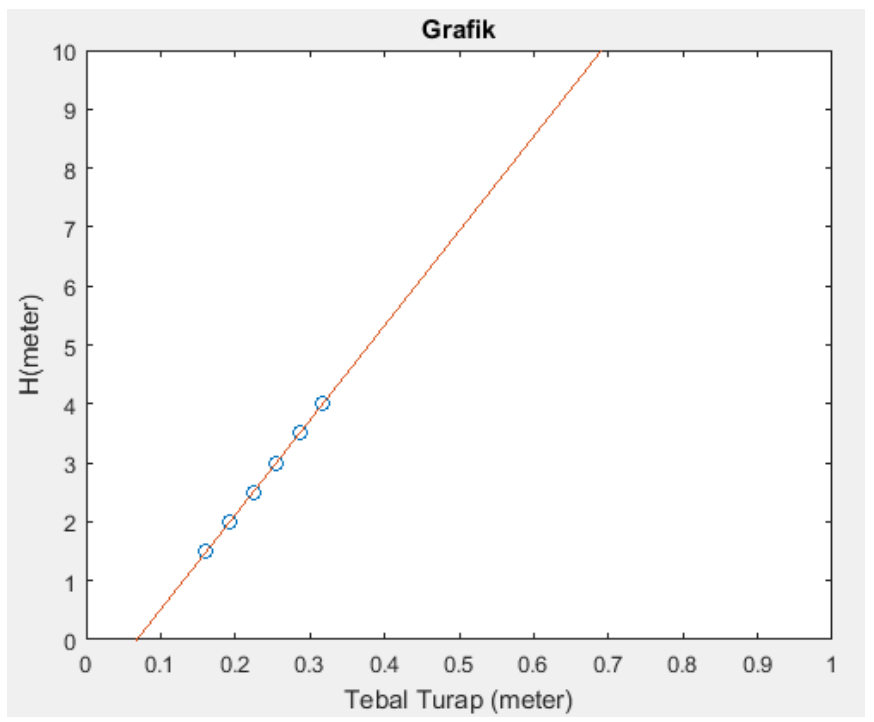

Gambar 4. Grafik Tebal Turap lebar 1 Meter

Persamaan Regresi $\mathrm{Y}=-1.0924+16.0546 \mathrm{x}$

2. Membuat suatu perancangan turap kayu dengan membuat suatu perencanaan tinggi turap $(\mathrm{H})$ yang akan dipasang dengan lebar 2 Meter dan berat volume tanah $(\gamma) 20 \mathrm{KN} / \mathrm{M}^{3}$. Adapun hasil perhitungan didapat pada tabel 3 dibawah. 
Ellyta Mona, Analisa Perhitungan Dimensi Turap Kayu (Panjang Kayu Ditanam Dan Tebal) Sebagai Dinding Penahan Tanah Sementara

Tabel 3. Hasil Perhitungan lebar 2 Meter dan volume $\operatorname{tanah}(\gamma) 20 \mathrm{KN} / \mathrm{M}^{3}$

\begin{tabular}{lcccccc}
\hline \multicolumn{7}{c}{$\left(20 \mathrm{KN}^{\mathrm{M}} \mathrm{M}^{3}\right)$} \\
\hline \multicolumn{1}{c}{ DIMENSi } & $\mathrm{H}(\mathrm{M})$ & $\mathrm{H}(\mathrm{M})$ & $\mathrm{H}(\mathrm{M})$ & $\mathrm{H}(\mathrm{M})$ & $\mathrm{H}(\mathrm{M})$ & $\mathrm{H}(\mathrm{M})$ \\
\hline Panjang turap itanam(M) & 1,5 & 2 & 2,5 & 3 & 3,5 & 4 \\
Tebal (M) & 1,666 & 2,222 & 2,777 & 3,333 & 3,888 & 4,444 \\
\hline
\end{tabular}

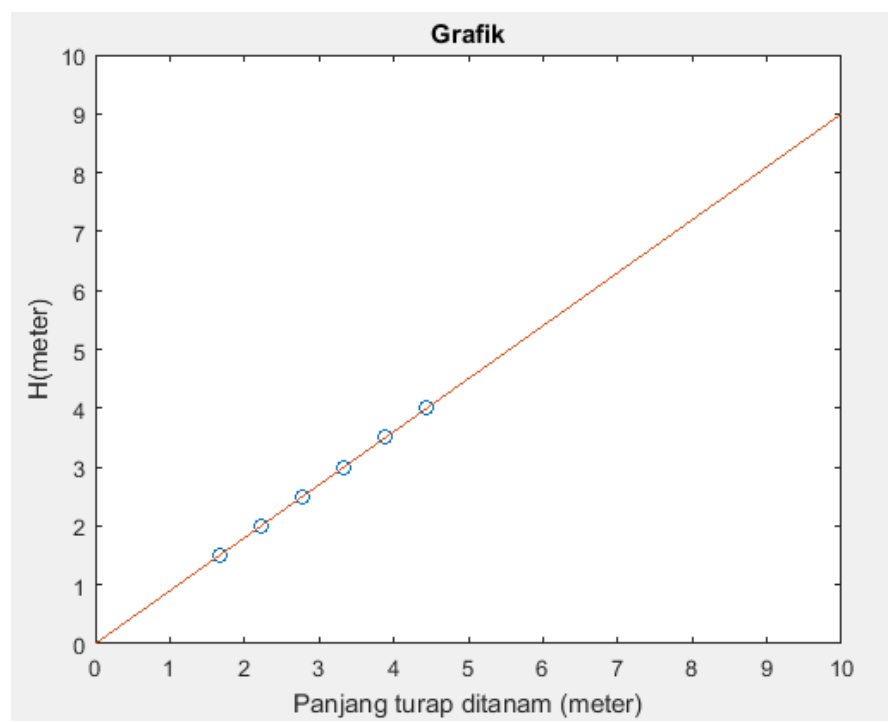

Gambar 5. Grafik Panjang Turap ditanam

Persamaan Regresi $Y=-0.0005+1.1111 \mathrm{x}$

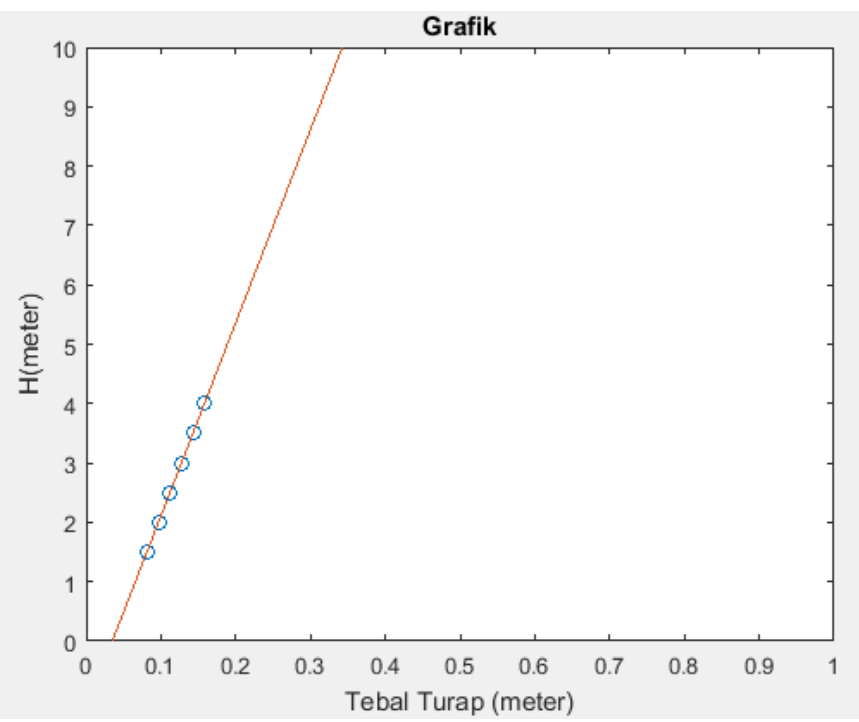

Gambar 6. Grafik Tebal Turap lebar 2 Meter

Persamaan Regresi $Y=-1.1421+32.5246 x$

3. Membuat suatu perancangan turap kayu dengan membuat suatu perencanaan tinggi turap $(\mathrm{H})$ yang akan dipasang dengan lebar 1 Meter dan berat volume tanah $(\gamma) \quad 30 \mathrm{KN} / \mathrm{M}^{3}$. Adapun hasil perhitungan didapat pada tabel 4 dibawah.

Tabel 4. Hasil Perhitungan lebar 1 Meter dan volume $\operatorname{tanah}(\gamma) 30 \mathrm{KN} / \mathrm{M}^{3}$

\begin{tabular}{|c|c|c|c|c|c|c|}
\hline \multicolumn{7}{|c|}{$\begin{array}{c}(\gamma) \\
\left(30 \mathrm{KN} / \mathrm{M}^{3}\right)\end{array}$} \\
\hline & $\mathrm{H}(\mathrm{M})$ & $\mathrm{H}(\mathrm{M})$ & $\mathrm{H}(\mathrm{M})$ & $\mathrm{H}(\mathrm{M})$ & $\mathrm{H}(\mathrm{M})$ & $\mathrm{H}(\mathrm{M})$ \\
\hline DIMENSI & 1,5 & 2 & 2,5 & 3 & 3,5 & 4 \\
\hline Panjang turap ditanam(M) & 1,666 & 2,222 & 2,777 & 3,333 & 3,888 & 4,444 \\
\hline Tebal (M) & 0,186 & 0,249 & 0,311 & 0,373 & 0,435 & 0,497 \\
\hline
\end{tabular}

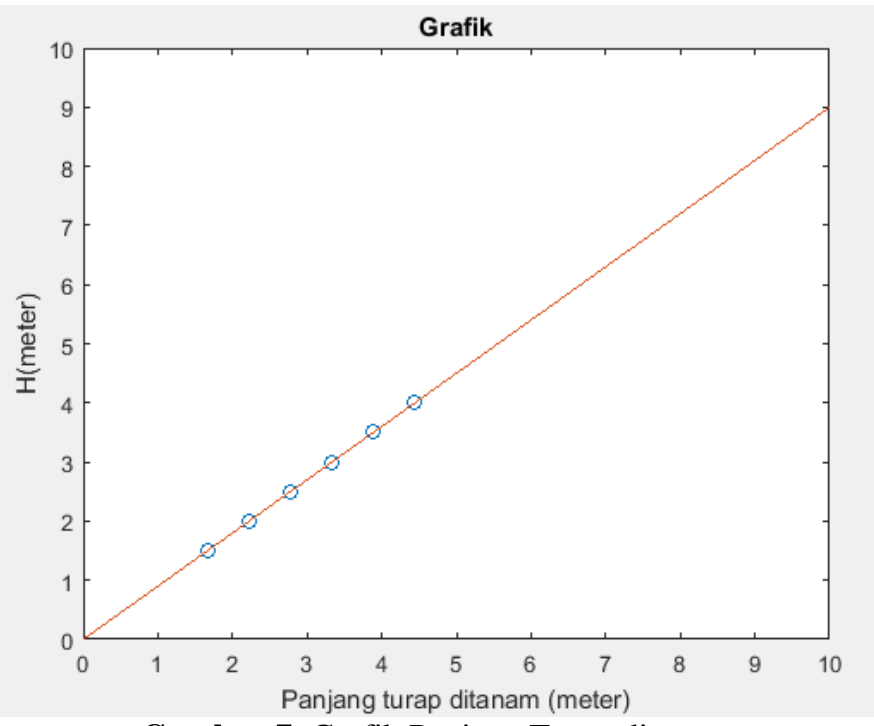

Gambar 7. Grafik Panjang Turap ditanam

Persamaan Regresi $\mathrm{Y}=-0.0005+1.1111 \mathrm{x}$

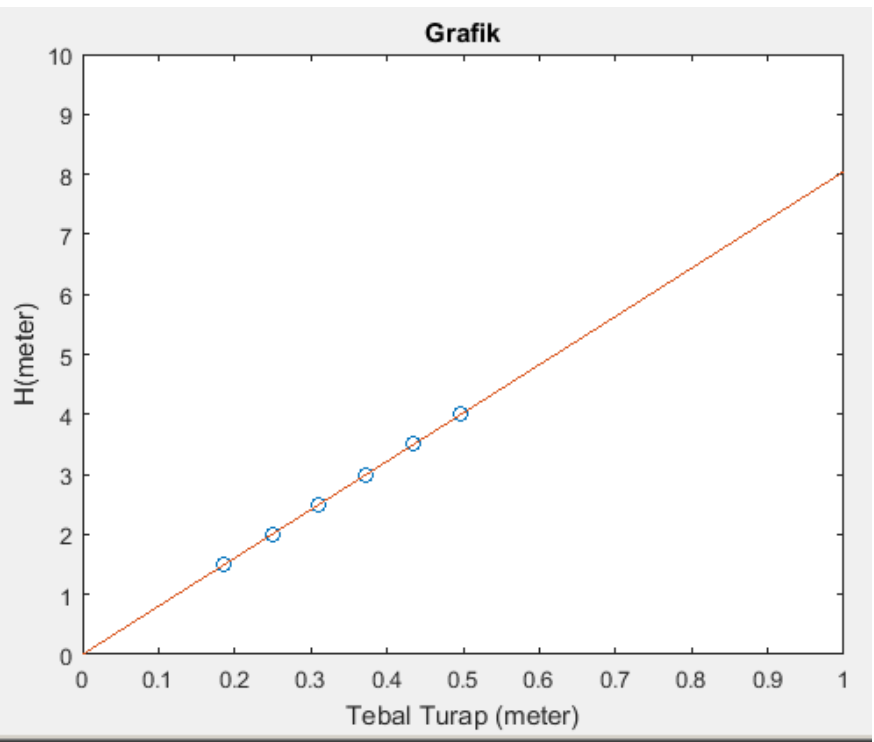

Gambar 8. Grafik Tebal Turap lebar 1 Meter

Persamaan Regresi $\mathrm{Y}=-0.0004+8.0459 \mathrm{x}$

4. Membuat suatu perancangan turap kayu dengan membuat suatu perencanaan tinggi turap $(\mathrm{H})$ yang akan dipasang dengan lebar 2 Meter dan berat volume tanah $(\gamma) \quad 30 \mathrm{KN} / \mathrm{M}^{3}$. Adapun hasil perhitungan didapat pada tabel 5 dibawah.

Tabel 5. Hasil Perhitungan lebar 2 Meter dan volume $\operatorname{tanah}(\gamma) 30 \mathrm{KN} / \mathrm{M}^{3}$

\begin{tabular}{|c|c|c|c|c|c|c|}
\hline \multicolumn{7}{|c|}{$\begin{array}{c}(\gamma) \\
\left(30 \mathrm{KN} / \mathrm{M}^{3}\right)\end{array}$} \\
\hline & $\mathrm{H}(\mathrm{M})$ & $\mathrm{H}(\mathrm{M})$ & $\mathrm{H}(\mathrm{M})$ & $\mathrm{H}(\mathrm{M})$ & $\mathrm{H}(\mathrm{M})$ & $\mathrm{H}(\mathrm{M})$ \\
\hline DIMENSI & 1,5 & 2 & 2,5 & 3 & 3,5 & 4 \\
\hline Panjang turap ditanam(M) & 1,666 & 2,222 & 2,777 & 3,333 & 3,888 & 4,444 \\
\hline Tebal (M) & 0,093 & 0.124 & 0,155 & 0,186 & 0,218 & 0,248 \\
\hline
\end{tabular}




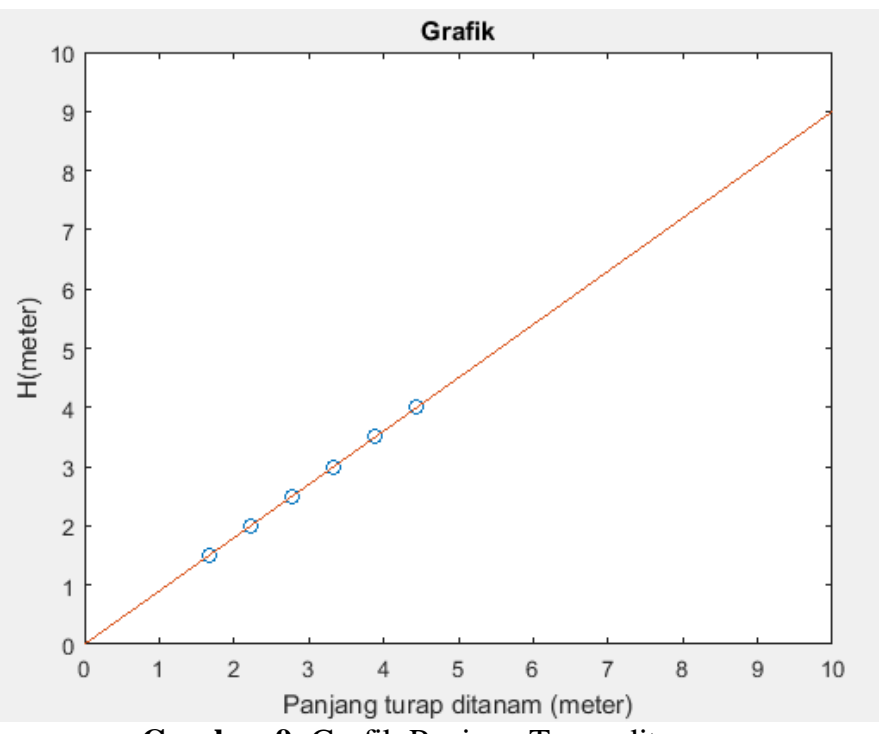

Gambar 9. Grafik Panjang Turap ditanam

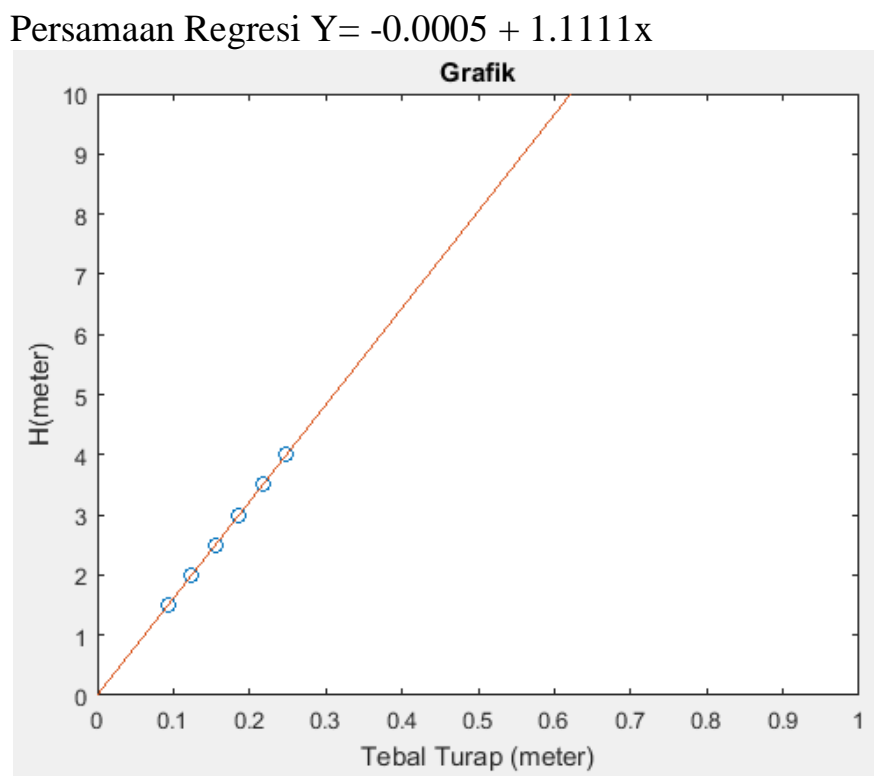

Gambar 10. Grafik Panjang Turap ditanam

Persamaan Regresi $\mathrm{Y}=0.0050+16.0839 \mathrm{x}$

\section{Pembahasan}

Berdasarkan hasil perhitungan perencanaan dimensi tebal dan panjang turap ditanam turap sementara (turap kayu) sebagai penahan tanah menggunakan Software MATLAB yang telah dilakukan didapatkan suatu persamaan Regresi Linier untuk dimensi turap. Persamaan ini dapat diaplikasi pada pelaksanaan pembangunan turap dengan lebar 1 meter dan 2 meter pada berat volume tanah berkisar dari $20 \mathrm{KN} / \mathrm{M}^{3}-30$ $\mathrm{KN} / \mathrm{M}^{3}$ dan tinggi turap 1 meter - 4 meter. Adapun dimensi turap adalah panjang turap ditanam dan tebal turap, untuk persamaan menghitung panjang turap adalah $\mathrm{Y}=-0.0005+1.1111 \mathrm{x}$, dimana $\mathrm{x}$ adalah panjang turap ditanam dan $\mathrm{Y}$ adalah tinggi turap. sedangkan untuk tebal turap adalah sbb:

1. Perencanaan lebar 1 Meter dan volume tanah $(\gamma) 20$ $\mathrm{KN} / \mathrm{M}^{3}$
Persamaan Regresi $\mathrm{Y}=-1.0924+16.0546 \mathrm{x}$

2. Perencanaan lebar 2 Meter dan volume tanah $(\gamma) 20$ $\mathrm{KN} / \mathrm{M}^{3}$

Persamaan Regresi $\mathrm{Y}=-1.1421+32.5246 \mathrm{x}$

3. Perencanaan lebar 1 Meter dan volume tanah $(\gamma) 30$ $\mathrm{KN} / \mathrm{M}^{3}$

Persamaan Regresi $\mathrm{Y}=-0.0004+8.0459 \mathrm{x}$

4. Perencanaan lebar 2 Meter dan volume tanah $(\gamma) 30$ $\mathrm{KN} / \mathrm{M}^{3}$

Persamaan Regresi $\mathrm{Y}=0.0050+16.0839 \mathrm{x}$

Dimana $\mathrm{x}$ adalah tebal turap dan $\mathrm{Y}$ adalah tinggi turap

\section{SIMPULAN}

Turap kayu sebagai turap sementara merupakan bahan kayu, material ini berfungsi sebagai penahan tanah yang tidak begitu tinggi. Hal ini disebabkan material kayu tak akan sanggup dalam menahan beban tanah maupun kerikil yang berlebihan. Dari hasil penelitian yang telah dilakukan, perencanaan turap kayu lebar 1 meter dan 2 meter sebagai dinding penahan tanah dan untuk volume tanah berkisar dari $20 \mathrm{KN} / \mathrm{M}^{3}-30$ $\mathrm{KN} / \mathrm{M}^{3}$ sedangkan tinggi turap 1 meter - 4 meter. Didapatkan bahwa panjang turap ditanam tidak mempengaruhi terhadap perubahan volume tanah sedangkan tebal kayu sangat mempengaruhi.

\section{DAFTAR PUSTAKA}

Bowles, Joseph E., (1997) Analisis dan Desain Pondasi, Jilid 1 dan 2, Erlangga,Jakarta, 1997

Day, R.W., Geotechnical and Foundation Engineering, McGraw-Hill, New York, 1999.

Eka Setyowati, 2012, Perencanaan Konstruksi Turap Sebagai Pengganti Dinding Penahan (Studi Kasus Jalan Lingkar Donggala)

Hardiyatmo, H.C., Teknik Fondasi I, Beta Offset, Yogyakarta, 2003.

Jambi Pos Online, "Hearing Komisi III DPRD Kota Jambi Soal RT 17 Paal V Kobar", 05 Oktober 2016, [online], Tersedia:http://www.jambiposonline.com/2016/10/hearing-komisi-iii-dprd-kotajambi-soal.html?m=0,[akses: 02 Juli 2021]

Martini, Shyama Maricar, Hendra Setiawan. 2012. Perencanaan Konstruksi Turap Sebagai Pengganti Dinding Penahan (Studi Kasus Jalan Lingkar Donggala) 